\title{
$I L-1 B-31 T>C$ promoter polymorphism is associated with gastric stump cancer but not with early onset or conventional gastric cancers
}

\author{
R. Sitarz • W. W. J. de Leng • M. Polak • \\ F. H. M. Morsink - O. Bakker • W. P. Polkowski • \\ R. Maciejewski - G. J. A. Offerhaus - A. N. Milne
}

Received: 6 February 2008 /Revised: 4 June 2008 / Accepted: 3 July 2008 /Published online: 8 August 2008

(C) The Author(s) 2008

\begin{abstract}
It has been reported that interleukin-1beta (IL-1B) genes play a crucial role in the genetic predisposition to gastric cancer although there is no information about their role in different subtypes of gastric cancer. We performed single nucleotide polymorphism analysis of IL-1B in 241 gastric cancers including early onset gastric cancers (EOGC), conventional gastric cancers, and gastric stump cancers (GSCs) as well as 100 control patients, using real-time polymerase chain reaction and sequence analysis. The $\mathrm{C}$ allele was present in $60 \%$ of EOGCs, $59 \%$ of conventional gastric cancers, and $90 \%$ of GSCs, compared to $62 \%$ in the control group. Interestingly, there was no difference between early onset and conventional gastric cancer with respect to the $I L-1 B-31 \mathrm{~T}>\mathrm{C}$ polymorphism distribution. A statistically significant difference in the presence of the $\mathrm{C}$ allele compared to the control
\end{abstract}

R. Sitarz $\cdot$ W. W. J. de Leng $\cdot$ F. H. M. Morsink $\cdot$

G. J. A. Offerhaus $\cdot$ A. N. Milne $(\square)$

Department of Pathology, H04-312,

University Medical Center Utrecht,

Postbox 85500, 3508 GA Utrecht, The Netherlands

e-mail: a.n.a.milne@umcutrecht.nl

R. Sitarz $\cdot$ R. Maciejewski

Department of Human Anatomy, Medical University of Lublin, Lublin, Poland

M. Polak · G. J. A. Offerhaus

Department of Pathology, Academic Medical Centre,

Amsterdam, The Netherlands

O. Bakker

Department of Endocrinology, Academic Medical Centre,

Amsterdam, The Netherlands

W. P. Polkowski

Department of Surgical Oncology, Medical University of Lublin, Lublin, Poland group was found in patients with gastric stump cancer ( $p=$ 0.008 ) with the $T$ allele conferring protection against gastric stump cancer. In summary, we have shown that the $I L-1 B$ $-31 \mathrm{C}$ allele promoter polymorphism is significantly associated with gastric stump cancer compared to the control group. Although several molecular differences have been identified between conventional gastric cancer and early onset gastric cancer, the $I L-1 B-31$ allele distribution is similar between these two groups.

Keywords $I L-1 B 31 \mathrm{~T}>\mathrm{C}$ polymorphism .

Early onset gastric cancer - Gastric stump cancer .

Conventional gastric cancer

\section{Introduction}

Although gastric cancer incidence decreases worldwide, it is still the second most common cause of cancer-related death in the world [35]. According to the Lauren classification [24], gastric cancer is divided into two main histological types, diffuse and intestinal. Gastric cancer results from a combination of environmental factors and accumulation of specific genetic alterations. In conventional gastric cancer (presenting $>45$ years old), environmental factors play a more important role, compared to early onset gastric cancer (EOGC, presenting at $\leq 45$ years old) where it is postulated that genetic factors may be more important [20]. We have previously shown that molecular differences exist between conventional gastric cancer and EOGC [4-6, 29-32]. Apart from cases of hereditary gastric cancer, it remains unclear what predisposes the young patients to gastric cancer at such an early age.

Helicobacter pylori, is a class I carcinogen [16] and is the main environmental factor causing gastric cancer [11, 
36]. H. pylori infection has been shown to range from approximately $60 \%$ in the general population to approximately $84 \%$ in patients with gastric cancer [36]. Only a few papers about $H$. pylori infection in gastric cancer patients younger than 40 years have been published, all showing an association between gastric cancer and $H$. pylori infection $[21,28,37]$. H. pylori is involved in both intestinal and diffuse types of gastric cancer, the latter type being more common in EOGC [37].

Interleukin-1beta (IL-1B) is a key pro-inflammatory cytokine, which regulates the expression of several genes involved in inflammation. IL-1B is an endogenous inhibitor of gastric acid secretion and is important in initiating and enhancing the inflammatory response to $H$. pylori infection $[34,43]$. Although the production of IL-1B depends on several factors, there is increasing evidence that the genetic background plays a major role. Therefore, single nucleotide polymorphisms (SNPs) in the $I L-1 B$ gene may be of importance in gene transcriptional activity.

Several single nucleotide polymorphisms in $I L-1 B$ have been studied, but many of these seem to be functionally insignificant and not associated with predisposition to cancer [7]. There are two biallelic polymorphisms at positions -31 and -511 in the promoter region of $I L-1 B$, of which the $-31 \mathrm{C}$ allele and the $-511 \mathrm{~T}$ allele are in positive linkage disequilibrium and associated with gastric cancer risk. It has been reported that carriers of the $I L-1 B-31 \mathrm{C}$ allele, showed higher plasmatic concentrations of IL-1B than subjects with wild-type $I L-1 B$ genotype [14]. Upregulation of IL-1B is involved in tumor-promoting effects such as invasiveness [40], angiogenesis [38], and metastasis [45] and has been recognized as negative prognostic factor, mainly in metastatic cancer [27]. Conversely, an association between peptic ulcer and the $I L-1 B-31 \mathrm{~T}$ polymorphism has been described $[8,9]$. Bearing this information in mind, the IL-1B status of patients with EOGC is of great interest. Whether these patients have a genetic predisposition for the carcinogenic pathway in response to H. pylori infection has never been investigated.
Several independent groups have found an association between partial gastrectomy (mostly after gastroduodenal ulcers) and increased risk for development of gastric cancer $[33,39]$. These so-called gastric stump cancers (GSCs) are carcinomas occurring in the gastric remnant at least 5 years after surgery for a benign disease [42]. This represents a novel group in terms of $I L-1 B$ polymorphisms in that they are patients who have a predisposition for gastroduodenal ulcers yet have also developed gastric cancer. The $I L-1 B$ status of gastric stump cancers has never been studied to date.

In this study, we examined the distribution of the $I L-1 B$ $-31 \mathrm{~T}>\mathrm{C}$ polymorphism in 241 gastric cancers including EOGC, conventional gastric cancer and GSC using real-time polymerase chain reaction (PCR) and sequence analysis and we investigated the relationship of $I L-1 B$ status with histology and location of the tumor.

\section{Materials and methods}

\section{Patients}

We used 96 conventional gastric cancers ( $>45$ years old) obtained from the Academic Medical Centre, Amsterdam diagnosed between 1993 and 2003. One hundred and fifteen early onset gastric cancers ( $\leq 45$ years old) diagnosed between 1980 and 2002, were obtained from 24 different institutions throughout The Netherlands through the nationwide database system and from the Department of Pathology at the Jorvi Hospital (Espoo, Finland) and 30 gastric stump cancers from the Amsterdam post-gastrectomy cohort [41]. The control group consisted of 100 DNA samples from the Department of Endocrinology at the Academic Medical Center, Amsterdam as published previously [44]. The tumors were classified by an experienced gastrointestinal pathologist (GJAO) according to the Lauren classification, as can be seen in Table 1. H. pylori vacA s region genotype and the presence of the cagA gene were known for 29 of the EOGC

Table 1 Patients' characteristics

\begin{tabular}{|c|c|c|c|c|}
\hline & No. of patients & Age (range) & Histology & Location \\
\hline Early onset gastric cancer (EOGC) & 115 & $\leq 45$ (21-45 years) & $\begin{array}{l}\text { Intestinal-25 }(22 \%) \\
\text { Diffuse-80 }(70 \%) \\
\text { Mixed-10 }(9 \%)\end{array}$ & $\begin{array}{l}\text { Cardia-9 }(8 \%) \\
\text { Non-cardia-66 }(57 \%) \\
\text { Unknown-40 }(35 \%)\end{array}$ \\
\hline Conventional gastric cancer & 96 & $>45$ ( $47-86$ years $)$ & $\begin{array}{l}\text { Intestinal-49 }(51 \%) \\
\text { Diffuse-36 }(38 \%) \\
\text { Mixed-11 }(11 \%)\end{array}$ & $\begin{array}{l}\text { Cardia }-49(51 \%) \\
\text { Non-cardia- } 41(43 \%) \\
\text { Unknown-6 }(6 \%)\end{array}$ \\
\hline Gastric stump cancer (GSC) & 30 & (54-85 years) & $\begin{array}{l}\text { Intestinal-26 }(87 \%) \\
\text { Diffuse-2 }(7 \%) \\
\text { Mixed-2 }(7 \%)\end{array}$ & Unknown \\
\hline Control group & 100 & (22-52 years) & None & None \\
\hline
\end{tabular}


cases as detected by PCR followed by agarose gel electrophoresis and as published previously [6]. H. pylori infection was detected in 11 of 29 (37.9\%) of these cases, a percentage which is in accordance with published data concerning The Netherlands population [25].

\section{DNA isolation}

DNA was isolated from formalin-fixed tissue using the QIAamp DNA mini kit (Qiagen, Venlo, The Netherlands) or the Puregene DNA isolation kit (Gentra, Minneapolis, USA) according to the manufacturer's instructions. Normal tissue was obtained from a tumor-free lymph node, or where necessary, from tissue with a small component of neoplastic cells. DNA concentrations were measured using the NanoDrop spectrophotometer (Isogen Life Science, IJsselstein, The Netherlands).

\section{Real-time PCR}

The polymorphism $-31 \mathrm{~T}>\mathrm{C}$ in the promoter region of $I L$ $1 B$ was detected using the LightCycler 2.0 (Roche, Mannheim, Germany) with 5'-ccctttcctttaacttgattgtgaaatc$3^{\prime}$ and 5'-aggtttggtatctgccagtttctc-3' (Applied Biosystems, Foster City, USA) as primers and the fluorescent probes 6FAM-5'-CTGTTTTTATAGCTTTCA-3-MBG', and VIC-5'CTGTTTTTATGGCTTTCA-3'-MGB (Applied Biosystems) in a 20 - $\mu$ l reaction mixture containing $10 \mu$ Q QuantiTect Probe PCR Kit (Qiagen, Leusden, The Netherlands), $10 \mathrm{pmol}$ forward and reverse primer, 2 pmol of each probe, and 50 ng genomic DNA. PCR conditions were as follows: $94^{\circ} \mathrm{C}$ for $15 \mathrm{~min}$ followed by 45 cycles of $94^{\circ} \mathrm{C}$ for $15 \mathrm{~s}$ and $60^{\circ} \mathrm{C}$ for 30 s. In each run, three positive control samples (TT, TC, and CC allele) as confirmed twice on sequencing were used together with water as a negative control.

\section{Sequencing}

To confirm the results from the real-time PCR, $10 \%$ of the samples were sequenced. The promoter region was amplified using the primers (forward) 5'-ccctttcctttaacttgattgtgaaatc-3' and (reverse) 5'-aggtttggtatctgccagtttctc-3' (Applied Biosystems). PCR products were purified using the QIAquick PCR purification kit (Qiagen), according to the manufacturer's instructions. The sequences were analyzed on an ABI 3100 automated sequencer (Applied Biosystems) using the ABI Big Dye Terminator Cycle Sequence Kit (Applied Biosystems) and the Genescan 2.1 software.

\section{Statistics}

The SPSS 14.0 software package was used for statistical analysis. A chi-squared test was applied to determine whether there was a statistical difference between the presence of the $\mathrm{C}$ and T allele $(p<0.05)$. The Hardy-Weinberg equilibrium was assessed using the chi-squared test. A multinominal logistic regression model was used to calculate the odds ratio for developing gastric cancer depending on SNP status, and also for adjusting for histological type and location (proximal versus distal only for EOGC and conventional gastric cancer).

\section{Results}

The identification of a genetic risk profile for gastric cancer could help the populations most at risk. Therefore, we evaluated the role of $I L-1 B-31 \mathrm{~T}>\mathrm{C}$ promoter polymorphism in different subtypes of gastric cancer. The distribution of the $I L-1 B-31 \mathrm{~T}>\mathrm{C}$ polymorphism was examined by real-time PCR (see Fig. 1) in 241 cases of gastric cancer, including 96 conventional gastric cancers, 115 EOGCs, and 30 GSCs as well as in 100 healthy control cases, and these results can be seen in Table 2, where the number of each specific genotype can be seen for each subtype of gastric cancer. In terms of carriage of the $\mathrm{C}$ allele, this was found in $60 \%$ of EOGCs, $59 \%$ of conventional gastric cancer, $90 \%$ of GSCs, and $62 \%$ of controls, as seen in the bottom row of Table 2 . The $I L-1 B$ polymorphism status was confirmed in $10 \%$ of our study populations, using sequence analysis, an example of which can be seen in Fig. 1. All genotypic distributions were in Hardy-Weinberg equilibrium ( $p \geq 0.05$ ).

A logistic regression model was used to determine the statistical likelihood of developing different subtypes of gastric cancer depending on the $I L-1 B$ SNP status. In this regression model, carriage of the $\mathrm{C}$ allele was compared between the different types of gastric cancer, with adjustments made for both histology and location of the tumor (for the categories of EOGC and conventional gastric cancer) and corrected for histology only in the case of stump cancers. In patients with GSC, carriage of the $\mathrm{C}$ allele conferred a significant increased risk of the development of gastric cancer with respect to the controls $(p=0.008, \mathrm{OR}=5.52,95 \%$ confidence interval 1.57-19.43). Carriage of the $\mathrm{C}$ allele (genotypes $\mathrm{CT}$ and $\mathrm{CC}$ ) in both EOGC and conventional gastric cancer did not confer an increased risk of gastric cancer with respect to the control group $(p=0.76$, OR $0.92,95 \%$ confidence interval $0.53-1.59$ and $p=0.71$, OR $0.9,95 \%$ confidence interval $0.51-1.59$, respectively).

Using a logistic regression model, the genotype distribution was also compared between EOGC, conventional gastric cancer, GSC, and the control group. In the gastric stump cancer group, the CC and CT genotypes predisposed to gastric cancer with an OR of $5.33(p=0.022,95 \%$ confidence interval 1.27-22.44) and $5.6(p=0.009,95 \%$ confidence interval 1.54-20.40), respectively. No difference was found 


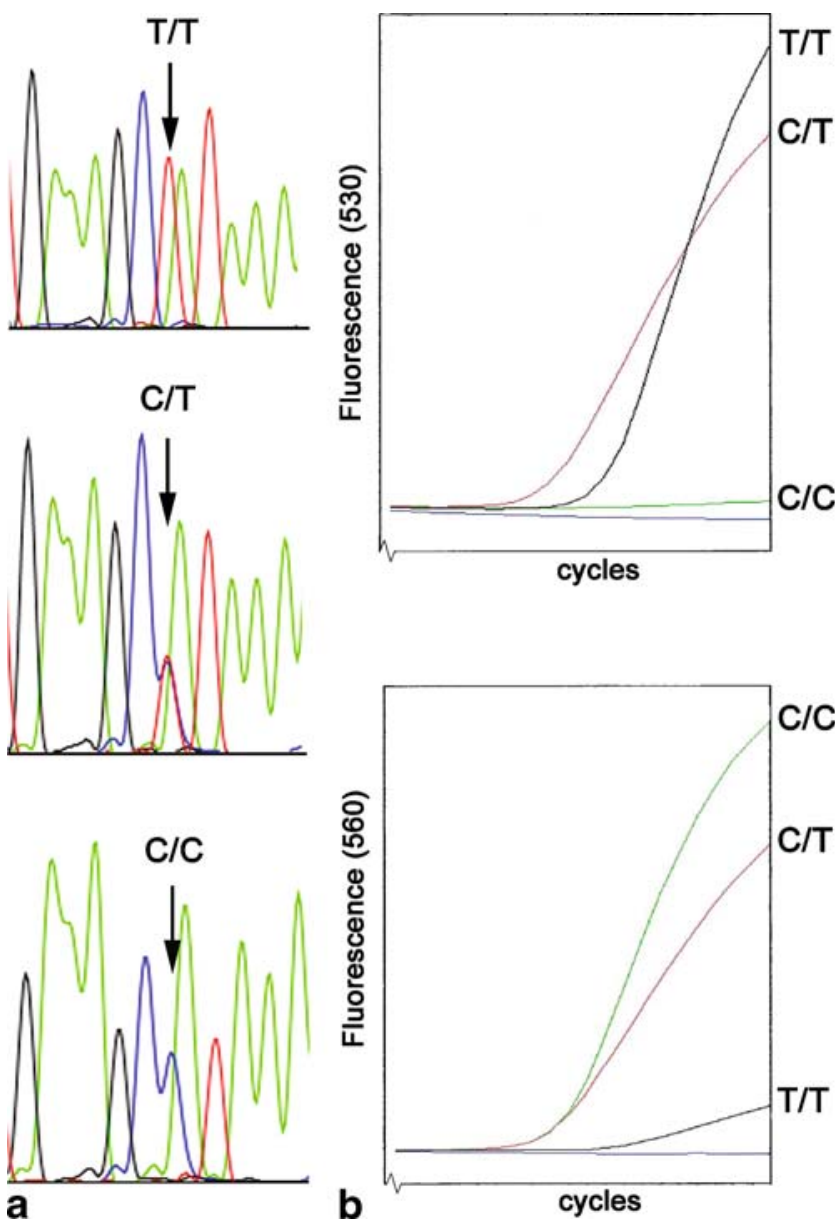

Fig. 1 Result of sequencing and LightCycler analysis. a An example of the sequence analysis of the CC, CT, and TT $I L-1 B$ polymorphism. b LightCycler analysis of CC, CT, and TT SNP genotypes at the -31 position of the promoter region of $I L-1 B$ using MGB probes. Upper panel shows the FAM-labeled probe, visualized at $530 \mathrm{~nm}$ for detection of the T allele; lower panel shows the VIC-labeled probe, visualized at $560 \mathrm{~nm}$ for detection of the $\mathrm{C}$ allele

in genotype distribution between EOGCs and conventional gastric cancers and the control group.

In addition, the $I L-1 B-31 \mathrm{~T}>\mathrm{C}$ genotype or carriage of the $\mathrm{C}$ allele did not predispose to a specific location of gastric cancer (cardia versus non-cardia, applicable to EOGC and conventional gastric cancers only) or to a histological type.

\section{Discussion}

Inflammation is a central component of several chronic diseases. $I L-1 B$ is an inducible gene that plays an important role in both inflammation and carcinogenesis. The expression of $I L-1 B$ depends on varying individual susceptibility, geographical location, and genetic factors. Genetic polymorphisms that alter the levels of IL-1B may have substantial influence on cancer activity. In the present study, we focused on the distribution of the $-31 \mathrm{~T}>\mathrm{C}$ promoter polymorphism of the human $I L-1 B$ gene in conventional gastric cancer, EOGC, and GSC.

The $I L-1 B-31 \mathrm{C}$ allele is reported to be associated with higher risk of gastric cancer [8,9]. Interestingly, we did not find an association between the pro-inflammatory genotype of $I L-1 B-31$ and predisposition to conventional or early onset gastric cancer. The role of $I L-1 B-31 \mathrm{~T}>\mathrm{C}$ polymorphism in gastric cancer has been variable and the literature is inconclusive. Positive associations between pro-inflammatory genotypes of $I L-1 B-31$ and higher risk of gastric cancer have been previously reported in populations from Poland, Scotland, and Mexico [8, 9, 12]. This is in contrast to studies in Finland [18] and Brazil [13], and our current findings are also in line with two published meta-analyses about the association of $I L-1 B$ polymorphisms with gastric cancer in a Caucasian population [3, 19]. It does appear that not all Asian or white populations have demonstrated a predisposition for gastric cancer in association with pro-inflammatory IL-1 polymorphisms and in some instances, studies found that there was a positive association, but with novel markers of the $I L-1 B$ gene [1]. So far, there is no clear explanation for these conflicting results although the relatively small number of gastric cancer cases (211) included in this particular study may provide an explanation for the negative association between the IL-1B marker and risk of GC. Zeng et al. [46] reported that the $I L-1 B$-genotype-dependent risk of gastric cancer was limited to specific areas where the prevalence of gastric cancer was low. This hypothesis, however, conflicts with data showing an association between the $I L-1 B-31 \mathrm{C}$ allele and gastric cancer in Poland and Portugal, two countries both with high prevalence rates of gastric cancer $[8,9,35]$. The effect of differing genetic and environmental

Table 2 Prevalence of $I L-1 B-31 \mathrm{~T}>\mathrm{C}$ genotype

\begin{tabular}{|c|c|c|c|c|}
\hline Genotype of $I L-1 B-31 \mathrm{~T}>\mathrm{C}$ & Early onset gastric cancer & Conventional gastric cancer & Gastric stump cancer & Controls \\
\hline $\mathrm{CC}$ & $17 / 115(15 \%)$ & $21 / 96(22 \%)$ & $8 / 30(27 \%)$ & $19(19 \%)$ \\
\hline $\mathrm{TC}$ & $52 / 115(45 \%)$ & $36 / 96(37 \%)$ & $19 / 30(63 \%)$ & $43(43 \%)$ \\
\hline $\mathrm{TT}$ & $46 / 115(40 \%)$ & $39 / 96(41 \%)$ & $3 / 30(10 \%)$ & $38(38 \%)$ \\
\hline Carriage of the $\mathrm{C}$ allele & $60 \%$ & $59 \%$ & $90 \%$ & $62 \%$ \\
\hline
\end{tabular}

All percentages rounded to the nearest digit. 
factors on different populations may provide an explanation for these conflicting reports. The importance of haplotype context has been highlighted in recent literature where polymorphisms in metabolic genes and in $\mathrm{CDH} 1$ have been shown to act in combination with smoking, alcohol consumption, and $H$. pylori infection in the development of gastric cancer $[2,17]$.

EOGC is a separate entity within gastric cancer and may result from different genetic alterations that accumulate more rapidly compared to conventional gastric cancer [6]. This is the first study that investigates the pro-carcinogenic background of EOGC by evaluating the role of the $I L-1 B$ $-31 \mathrm{~T}>\mathrm{C}$ polymorphism in predisposition to EOGC. We demonstrated that the distribution of the $I L-1 B-31 \mathrm{~T}>\mathrm{C}$ polymorphism is not different between EOGC and the control group and that there is no difference between conventional gastric cancer and EOGC for the $I L-1 B-31$ polymorphism. Thus, once infected by $H$. pylori (which appears to occur at the same rate as in conventional gastric cancers [6]), the IL1B status does not explain the increased risk of gastric cancer in these young patients.

An intriguing subtype of gastric cancer is gastric stump cancer, due to its gastroduodenal ulcer and partial gastrectomy history and subsequent gastric cancer development. It is described that gastric cancer and duodenal peptic ulcer disease are inversely associated, have distinct gastric acid secretion [10], and possess a distinct $I L-1 B-31 \mathrm{~T}>\mathrm{C}$ genotype distribution. It is believed that subjects who develop duodenal ulcers are actually protected from developing gastric cancer, suggesting that the two outcomes are mutually exclusive [15].

In the GSC patients, who developed peptic ulcer and gastric cancer, we found a statistically significant difference in $I L-1 B-31 \mathrm{~T}>\mathrm{C}$ polymorphism compared to the control group, with the $\mathrm{C}$ allele being associated with cancer. These findings are surprising as although the patients in this unique subgroup have a strong history of gastroduodenal ulcer, they do not have the polymorphism reportedly associated with ulcers but rather have a predilection for the $\mathrm{C}$ allele, which may explain the increased cancer risk in these patients. Although our gastric stump cancer group is small (30 patients), it seems that the $I L-1 B-31 \mathrm{~T}>\mathrm{C}$ polymorphism influences the prognosis of patients after partial gastrectomy. Although individuals with duodenal ulcers generally do not have the $\mathrm{C}$ polymorphism, the minority does appear to be at risk of developing gastric stump cancer. Surgery removes the inflamed and $H$. pylori-ridden antrum and induces acid suppression, thus converting these from an antrum-predominant into a corpus-predominant phenotype (to some extent comparable to the pharmacological acid suppression group) [22, 23]. In addition, these patients with the $C$ genotype are known to have an associated high IL-1B output which further increases the acid suppression thus increasing their risk of subsequent development of gastric cancer.
Researchers have reported significant associations between $I L-1 B$ promoter region polymorphisms and the anatomic site of the tumor and histology. Machado et al. reported that the $I L-1 B-511 \mathrm{~T}(-31 \mathrm{C})$ genotype is associated with an intestinal type of gastric cancer in a Portuguese population [26] and Garza-Gonzalez et al. described the association between the $I L-1 B-31 \mathrm{C}$ genotype and the risk of distal gastric cancer in a Hispanic population [12]. We examined the associations between $I L-1 B-31 \mathrm{~T}>\mathrm{C}$ polymorphisms and location of the tumor or the histology and found no relation. This discrepancy is most likely due to study size, as in our study, where we have assessed a total of 241 gastric cancers, in contrast to the 152 and 63 used by Machado et al. and Garza-Gonzalez et al., respectively, and thus, it is likely that there is no correlation between histology and IL-1B genotype. On the other hand, the high rate of $H$. pylori infection in countries such as Portugal may result in the IL-1B polymorphism playing a more important role in the development of intestinal gastric cancer in this particular population.

In summary, this is the first study describing the role of the $I L-1 B-31 \mathrm{~T}>\mathrm{C}$ polymorphism in EOGC and GSC. Although EOGC appears to have a different genetic background compared to conventional gastric cancer, we did not find any differences in the $I L-1 B-31 \mathrm{~T}>\mathrm{C}$ polymorphism distribution. Interestingly, our study has shown that the $I L-1 B-31 \mathrm{C}$ genotype can contribute significantly to the development of GSC.

Acknowledgments The authors thank Sjoerd Repping from the Endocrinology Department, Academic Medical Centre, Amsterdam, for provision of the control group. Robert Sitarz, first author, is funded by the Stella Major Foundation.

Conflict of interest statement We declare that we have no conflict of interest.

Open Access This article is distributed under the terms of the Creative Commons Attribution Noncommercial License which permits any noncommercial use, distribution, and reproduction in any medium, provided the original author(s) and source are credited.

\section{References}

1. Amieva MR, El-Omar EM (2008) Host-bacterial interactions in Helicobacter pylori infection. Gastroenterology 134:306-323

2. Boccia S, Sayed-Tabatabaei FA, Persiani R, Gianfagna F, Rausei S, Arzani D, La Greca A, D'Ugo D, La Torre G, van Duijn CM, Ricciardi G (2007) Polymorphisms in metabolic genes, their combination and interaction with tobacco smoke and alcohol consumption and risk of gastric cancer: a case-control study in an Italian population. BMC Cancer 7:206

3. Camargo MC, Mera R, Correa P, Peek RM Jr, Fontham ET, Goodman KJ, Piazuelo MB, Sicinschi L, Zabaleta J, Schneider BG (2006) Interleukin-1beta and interleukin-1 receptor antagonist gene polymorphisms and gastric cancer: a meta-analysis. Cancer Epidemiol Biomarkers Prev 15:1674-1687 
4. Carvalho R, Milne AN, Polak M, Corver WE, Offerhaus GJ, Weterman MA (2005) Exclusion of RUNX3 as a tumour-suppressor gene in early-onset gastric carcinomas. Oncogene 24:8252-8258

5. Carvalho R, Milne AN, Polak M, Offerhaus GJ, Weterman MA (2006) A novel region of amplification at 11p12-13 in gastric cancer, revealed by representational difference analysis, is associated with overexpression of CD44v6, especially in early-onset gastric carcinomas. Genes Chromosomes Cancer 45:967-975

6. Carvalho R, Milne AN, van Rees BP, Caspers E, Cirnes L, Figueiredo C, Offerhaus GJ, Weterman MA (2004) Early-onset gastric carcinomas display molecular characteristics distinct from gastric carcinomas occurring at a later age. J Pathol 204:75-83

7. Chen H, Wilkins LM, Aziz N, Cannings C, Wyllie DH, Bingle C, Rogus J, Beck JD, Offenbacher S, Cork MJ, Rafie-Kolpin M, Hsieh CM, Kornman KS, Duff GW (2006) Single nucleotide polymorphisms in the human interleukin-1B gene affect transcription according to haplotype context. Hum Mol Genet 15:519-529

8. El-Omar EM, Carrington M, Chow WH, McColl KE, Bream JH, Young HA, Herrera J, Lissowska J, Yuan CC, Rothman N, Lanyon G, Martin M, Fraumeni JF Jr, Rabkin CS (2000) Interleukin-1 polymorphisms associated with increased risk of gastric cancer. Nature 404:398-402

9. El-Omar EM, Carrington M, Chow WH, McColl KE, Bream JH, Young HA, Herrera J, Lissowska J, Yuan CC, Rothman N, Lanyon G, Martin M, Fraumeni JF Jr, Rabkin CS (2001) The role of interleukin-1 polymorphisms in the pathogenesis of gastric cancer. Nature 412:99

10. El-Omar EM, Oien K, El-Nujumi A, Gillen D, Wirz A, Dahill S, Williams C, Ardill JE, McColl KE (1997) Helicobacter pylori infection and chronic gastric acid hyposecretion. Gastroenterology 113:15-24

11. Forman D, Newell DG, Fullerton F, Yarnell JW, Stacey AR, Wald N, Sitas F (1991) Association between infection with Helicobacter pylori and risk of gastric cancer: evidence from a prospective investigation. BMJ 302:1302-1305

12. Garza-Gonzalez E, Bosques-Padilla FJ, El-Omar E, Hold G, Tijerina-Menchaca R, Maldonado-Garza HJ, Perez-Perez GI (2005) Role of the polymorphic IL-1B, IL-1RN and TNF-A genes in distal gastric cancer in Mexico. Int J Cancer 114:237-241

13. Gatti LL, Burbano RR, de Assumpcao PP, Smith Mde A, Payao SL (2004) Interleukin-1beta polymorphisms, Helicobacter pylori infection in individuals from northern Brazil with gastric adenocarcinoma. Clin Exp Med 4:93-98

14. Hall SK, Perregaux DG, Gabel CA, Woodworth T, Durham LK, Huizinga TW, Breedveld FC, Seymour AB (2004) Correlation of polymorphic variation in the promoter region of the interleukin-1 beta gene with secretion of interleukin-1 beta protein. Arthritis Rheum 50:1976-1983

15. Hunt RH (1996) The role of Helicobacter pylori in pathogenesis: the spectrum of clinical outcomes. Scand J Gastroenterol Suppl 220:3-9

16. IARC Working Group (1994) Schistosomes, liver flukes and Helicobacter pylori. IARC Working Group on the evaluation of carcinogenic risks to humans. Lyon, 7-14 June 1994. IARC Monogr Eval Carcinog Risks Hum 61:1-241

17. Jenab M, McKay JD, Ferrari P, Biessy C, Laing S, Capella Munar GM, Sala N, Pena S, Crusius JB, Overvad K, Jensen MK, Olsen A, Tjonneland A, Clavel-Chapelon F, Boutron-Ruault MC, Kaaks R, Linseisen J, Boeing H, Bergmann MM, Trichopoulou A, Georgila C, Psaltopoulou T, Mattiello A, Vineis P, Pala V, Palli D, Tumino R, Numans ME, Peeters PH, Bueno-de-Mesquita HB, Lund E, Ardanaz E, Sanchez MJ, Dorronsoro M, Navarro Sanchez C, Quiros JR, Hallmans G, Stenling R, Manjer J, Regner S, Key T, Bingham S, Khaw KT, Slimani N, Rinaldi S, Boffetta P, Carneiro F, Riboli E, Gonzalez C (2008) CDH1 gene polymorphisms, smoking, Helicobacter pylori infection and the risk of gastric cancer in the
European Prospective Investigation into Cancer and Nutrition (EPIC-EURGAST). Eur J Cancer 44:774-780

18. Kamangar F, Abnet CC, Hutchinson AA, Newschaffer CJ, Helzlsouer K, Shugart YY, Pietinen P, Dawsey SM, Albanes D, Virtamo J, Taylor PR (2006) Polymorphisms in inflammationrelated genes and risk of gastric cancer (Finland). Cancer Causes Control 17:117-125

19. Kamangar F, Cheng C, Abnet CC, Rabkin CS (2006) Interleukin1B polymorphisms and gastric cancer risk-a meta-analysis. Cancer Epidemiol Biomarkers Prev 15:1920-1928

20. Kikuchi S, Nakajima T, Nishi T, Kobayashi O, Konishi T, Inaba Y, Wada O, Satou H, Ishibashi T, Ichikawa S, Okamoto N, Hirata T, Kubo T, Sato N, Miki K, Myoga A (1996) Association between family history and gastric carcinoma among young adults. Jpn J Cancer Res 87:332-336

21. Koshida Y, Koizumi W, Sasabe M, Katoh Y, Okayasu I (2000) Association of Helicobacter pylori-dependent gastritis with gastric carcinomas in young Japanese patients: histopathological comparison of diffuse and intestinal type cancer cases. Histopathology 37:124-130

22. Kuipers EJ, Lee A, Klinkenberg-Knol EC, Meuwissen SG (1995) Review article: the development of atrophic gastritis-Helicobacter pylori and the effects of acid suppressive therapy. Aliment Pharmacol Ther 9:331-340

23. Kuipers EJ, Lundell L, Klinkenberg-Knol EC, Havu N, Festen HP, Liedman B, Lamers CB, Jansen JB, Dalenback J, Snel P, Nelis GF, Meuwissen SG (1996) Atrophic gastritis and Helicobacter pylori infection in patients with reflux esophagitis treated with omeprazole or fundoplication. N Engl J Med 334:1018-1022

24. Lauren $P$ (1965) The two histological main types of gastric carcinoma: diffuse and so-called intestinal-type carcinoma. An attempt at a histo-clinical classification. Acta Pathol Microbiol Scand 64:31-49

25. Lunet N, Barros H (2003) Helicobacter pylori infection and gastric cancer: facing the enigmas. Int J Cancer 106:953-960

26. Machado JC, Pharoah P, Sousa S, Carvalho R, Oliveira C, Figueiredo C, Amorim A, Seruca R, Caldas C, Carneiro F, Sobrinho-Simoes M (2001) Interleukin 1B and interleukin 1RN polymorphisms are associated with increased risk of gastric carcinoma. Gastroenterology 121:823-829

27. Mahmoud FA, Rivera NI (2002) The role of C-reactive protein as a prognostic indicator in advanced cancer. Curr Oncol Rep 4:250-255

28. Masuda G, Tokunaga A, Shirakawa T, Togashi A, Kiyama T, Kato S, Matsukura N, Bou H, Watanabe M, Tajiri T (2007) Helicobacter pylori infection, but not genetic polymorphism of CYP2E1, is highly prevalent in gastric cancer patients younger than 40 years. Gastric Cancer 10:98-103

29. Milne AN, Carvalho R, Jansen M, Kranenbarg EK, van de Velde CJ, Morsink FM, Musler AR, Weterman MA, Offerhaus GJ (2008) Cyclin E low molecular weight isoforms occur commonly in early-onset gastric cancer and independently predict survival. J Clin Pathol 61:311-316

30. Milne AN, Carvalho R, Morsink FM, Musler AR, de Leng WW, Ristimaki A, fferhaus GJ (2006) Early-onset gastric cancers have a different molecular expression profile than conventional gastric cancers. Mod Pathol 9:564-572

31. Milne AN, Sitarz R, Carvalho R, Carneiro F, Offerh, aus GJ (2007) Early onset gastric cancer: on the road to unraveling gastric carcinogenesis. Curr Mol Med 7:15-28

32. Milne AN, Sitarz R, Carvalho R, Polak MM, Ligtenberg M, Pauwels P, Offerhaus GJ, Weterman MA (2007) Molecular analysis of primary gastric cancer, corresponding xenografts, and 2 novel gastric carcinoma cell lines reveals novel alterations in gastric carcinogenesis. Hum Pathol 38:903-913

33. Nicholls JC (1979) Stump cancer following gastric surgery. World J Surg 3:731-736 
34. Noach LA, Bosma NB, Jansen J, Hoek FJ, van Deventer SJ, Tytgat GN (1994) Mucosal tumor necrosis factor-alpha, interleukin-1 beta, and interleukin-8 production in patients with Helicobacter pylori infection. Scand J Gastroenterol 29:425-429

35. Parkin DM, Bray F, Ferlay J, Pisani P (2005) Global cancer statistics, 2002. CA Cancer J Clin 55:74-108

36. Parsonnet J, Friedman GD, Vandersteen DP, Chang Y, Vogelman JH, Orentreich N, Sibley RK (1991) Helicobacter pylori infection and the risk of gastric carcinoma. N Engl J Med 325:1127-1131

37. Rugge M, Busatto G, Cassaro M, Shiao YH, Russo V, Leandro G, Avellini C, Fabiano A, Sidoni A, Covacci A (1999) Patients younger than 40 years with gastric carcinoma: Helicobacter pylori genotype and associated gastritis phenotype. Cancer 85:2506-2511

38. Saijo Y, Tanaka M, Miki M, Usui K, Suzuki T, Maemondo M, Hong X, Tazawa R, Kikuchi T, Matsushima K, Nukiwa T (2002) Proinflammatory cytokine IL-1 beta promotes tumor growth of Lewis lung carcinoma by induction of angiogenic factors: in vivo analysis of tumor-stromal interaction. J Immunol 169:469-475

39. Sinning C, Schaefer N, Standop J, Hirner A, Wolff M (2007) Gastric stump carcinoma-epidemiology and current concepts in pathogenesis and treatment. Eur J Surg Oncol 33:133-139

40. Song X, Voronov E, Dvorkin T, Fima E, Cagnano E, Benharroch D, Shendler Y, Bjorkdahl O, Segal S, Dinarello CA, Apte RN (2003) Differential effects of IL-1 alpha and IL-1 beta on tumorigenicity patterns and invasiveness. J Immunol 171:6448-6456
41. Tersmette AC, Offerhaus GJ, Giardiello FM, Brand R, Tersmette KW, Tytgat GN, Vandenbroucke JP (1991) Long-term prognosis after partial gastrectomy for benign conditions. Survival and smoking-related death of 2633 Amsterdam postgastrectomy patients followed up since surgery between 1931 and 1960. Gastroenterology 101:148-153

42. Thorban S, Bottcher K, Etter M, Roder JD, Busch R, Siewert JR (2000) Prognostic factors in gastric stump carcinoma. Ann Surg 231:188-194

43. Wallace JL, Cucala M, Mugridge K, Parente L (1991) Secretagoguespecific effects of interleukin-1 on gastric acid secretion. Am J Physiol 261:G559-G564

44. Westerveld H, Visser L, Tanck M, van der Veen F, Repping S (2008) CAG repeat length variation in the androgen receptor gene is not associated with spermatogenic failure. Fertil Steril 89:253259

45. Yano S, Nokihara $H$, Yamamoto A, Goto $H$, Ogawa $H$, Kanematsu T, Miki T, Uehara H, Saijo Y, Nukiwa T, Sone S (2003) Multifunctional interleukin-1beta promotes metastasis of human lung cancer cells in SCID mice via enhanced expression of adhesion-, invasion- and angiogenesis-related molecules. Cancer Sci 94:244-252

46. Zeng ZR, Hu PJ, Hu S, Pang RP, Chen MH, Ng M, Sung JJ (2003) Association of interleukin $1 \mathrm{~B}$ gene polymorphism and gastric cancers in high and low prevalence regions in China. Gut 52:1684-1689 